\title{
Linx
}

Revue des linguistes de l'université Paris X Nanterre

$13 \mid 2020$

Collocations et traditions discursives

\section{A Phraseodidactic Approach to Native Italians Comprehension of Spanish Press Information}

Ester Mellado Blanes

\section{OpenEdition}

Journals

\section{Electronic version}

URL: http://journals.openedition.org/linx/4168

DOI: $10.4000 / \operatorname{linx} .4168$

ISSN: 2118-9692

Publisher

Presses universitaires de Paris Nanterre

\section{Electronic reference}

Ester Mellado Blanes, «A Phraseodidactic Approach to Native Italians Comprehension of Spanish Press Information», Linx [Online], 13| 2020, Online since 30 May 2020, connection on 01 June 2020. URL : http://journals.openedition.org/linx/4168; DOI : https://doi.org/10.4000/linx.4168

This text was automatically generated on 1 June 2020

Département de Sciences du langage, Université Paris Ouest 


\title{
A Phraseodidactic Approach to Native Italians Comprehension of Spanish Press Information
}

\author{
Ester Mellado Blanes
}

\section{The context}

1 The research has been developed in the Università degli Studi di Modena and Reggio Emilia (or Unimore), in the Department of Studies on Language and Culture, applying the investigation to the degree of Lingue e Culture Europee. This degree is taken by a majority of native Italians from the area of Modena and surroundings. These students demonstrate good knowledge of both the Spanish language and its historical context, as social aspects are highly taken into account in the degree. With the contribution of this project, it is intended that students attain connection with cultural contents conveyed through real Spanish material, by concentrating on its phraseological aspects. The plurilingual profile that Italian inhabitants naturally have will provide a fruitful field of study to search for the strategies used in their awareness process of this specific linguistic aspect in Spanish.

\section{State of the art}

\subsection{Cognitive linguistics}

2 The line of research of cognitive linguistics explored the relation of language structure to things outside language, cognitive principles and mechanisms not specific to language, including notions of human categorization. The common belief of cognitive linguistics is that meaning is so inherent to language that it must be the centre of attention. Linguistic models provide the possibility of conveying meanings and so the 
mappings between connotation and form are a major issue of linguistic analysis. Thus, semantic structures of all meaningful linguistic units can and should be investigated.

\subsection{Cognitive linguistics in language learning}

3 "Language is a set of signs and notions through which an external image is related with its imagined projection in the brain" (Luque Durán 2004: 103). Therefore, "categorizing is the mental operation through which the external image connection and its internal projection are connected" (Compagno/Di Gesù 2003: 52). The relationship between these different modes of categorizing -that would correspond to different languagesand their function in human brain form a significant field of exploration.

Language is an innate human ability that, as any biological process, develops through time and space. This evolution is influenced by cultural factors. This root founds the basis for language learning. In early times, humans did not learn languages by means of formalist rules, but by means of real practices of communication, following the same perceptive rules that made them discover the keys of survival. Nowadays, this legacy is still present in brain structures, as some scientific experiments prove. To conclude, learning a language means a process of adaptation to the universe shaped by that language. A real and good acquisition of a language must be considered in the bounds of the culture where it is spoken.

\subsection{Interlanguage, intercomprehension and plurilingualism}

To shape the integrative didactic approach, it is crucial to take into consideration the learner's interlanguage level. Interlanguage theory, coined by Selinker in 1969, postulates that the second language learner's system is in an intermediate and detached position between the native and the target language. In this sense, this theory connects with the cognitive linguistics principles.

Nowadays it is known that languages are not learned one after the other or differently stored. Contrarily, what is known from one language is a springboard to know more of another language, so that the greater knowledge of language, the better chances of new language learning (cf. Candelier, 2003). This view marries the consideration that there is one common multilingual competence that is expressed through different languages. Following this line of work, research has supported the existence of an underlying common competence for multiple languages. This competence would explain the simultaneous use of diverse languages that subjects with plurilingual competences do (cf. Cummins 2000; Vila, Siqués, Roig 2006), showing remarkable metacognitive abilities (cf. Herdina, Jessner 2002). It is in the light of these investigations that the Council of Europe proposes a linguistic objective that considers these plurilingual and pluricultural notions, where speakers do not provide a collection of competences to communicate different and separate languages, but one plurilingual and pluricultural competence that includes the whole of their linguistic repertories.

7 Intercomprehension is based on the assumption that we have unconscious skills and mechanisms that we use to move from one language to another. However, it is important not to detach language and culture, as language is the vehicle of the society where it belongs. Some cultural - and so often opaque - aspects from a language are 
memorized with more difficulty by students, because they were not primarily understood.

\subsection{Phraseology}

8 Phraseology plays a main role in the acquisition of a foreign language. Within linguistics studies, phraseology would be highly connected to the field of pragmatics, which considers how the use of language influences the meaning of words and in which way it modifies the internal relationship between the denotative and the cognitive level. "Pragmatics is a subfield of linguistics which focuses on the connections between language and its use to describe reality, and takes into consideration the analysis of the context and how it affects the interpretation of meanings" (Di Gesú, 2012: 109).

Nowadays, the union of cognitive linguistics and phraseology is evolving towards a new paradigm. The application of the theory of the prototypes from cognitive linguistics constitutes a frame where different categories would not be closed compartments. In cognitive linguistics, lexicon, morphology and syntax are conceived as a continuum of interrelated aspects and not as separate components. Cognitive linguistics studies real language, which is why idiomatic expressions are considered as part of it, even when they do not follow the main principles of grammar. In summary, "the focus of attention is function, meaning and use, considering the form as a vehicle by which meaning is manifested" (Fernández, 2012: 36). The main postulate of cognitive linguistics is that language cannot be understood as a complete whole of mathematic rules (as in generativism), but as an irregular system where syntax, semantics and pragmatics work simultaneously to form the idealized cognitive models that shape our thought. So, there is not a clear separation between linguistic and encyclopedical or cultural knowledge. Besides, "cognitivists assume that language is by definition imaginative and creative, and its development has to be integrated in pragmatical use" (Fernández, 2012: 37).

\subsection{Phraseodidactics}

10 Phraseodidactics is a field which needs to be especially considered, as it is not easily acquired by foreign learners of a language. As Higueras García (2006: 97, author's translation) asserts, "it is surprising that there is little or no importance given to the training of linguists as well as to the training of professors of ELE in the field of phraseology".

Our vision of the world is organized through one of the most productive cognitive processes from the linguistic point of view, the metaphor, and this process is clearly reflected on the organization of phraseological units. It is thanks to metaphorical processes that we are able to understand and display a certain concept by means of another which is more familiar. It is this cognitive process that is on the root of a good number of phraseological concepts difficult to understand if not filtered thorough metaphorical processes. (Núñez 2015: 159, author's translation)

11 Consequently, the comprehension of figurative language is strictly linked to the communicative competence of a language. "Communicative competence requires metaphors to transmit and catch the figurative sense, ironies and connotations of phraseologisms" (Navarro 2003:103, author's translation). 

competences" (Martí 2016: 60). The inclusion of the cultural competence complements the formation of the linguistic competence, as if they were two sides of a coin. "One cannot exist without the other" (Sevilla 2007: 170, author's translation). If we introduce more knowledge about the context, we propitiate a greater motivated compositionality. This will increase the level of transparency of an idiom, which will become useful especially in the field of phraseodidactics. Indeed, some experiments, such as the ones carried out by Gibbs, demonstrated the importance of context when learning and remembering phraseological items ${ }^{1}$.

13 Another competence involved would be the figurative competence, defined by Cacciari ${ }^{2}$ as the ability to go beyond a literal-referential strategy and to use contextual information to construct a coherent semantic representation (cf. Levorato/Cacciari 1995). "Coseriu's theory on the link between language and culture, in which language is understood as a primary form of culture, justifies the treatment of these expressions from the field of ethnolinguistics, as a symbol of a community" (Biris 2014: 30).

coation of connotative meaning is conceived as a pragmatic fact inextricably linked to the context of use of the phrase in question. "It is our experience of the world, our encyclopaedic knowledge, which gives a new sense loaded with subjectivity and depending on the situation in which it develops" (Mellado 2013: 307, author's translation). "Words are stored in the lexicon not as in a dictionary, but as networks" (Higueras 2006: 15, author's translation).

15 According to these assertions, I confirm the need of a phraseodidactic approach which moves away from formal instruction, but takes into consideration a contextual methodology which favours the recognition, and thus, the acquisition of idiomatic elements ${ }^{3}$.

Following a cognitive perspective, the acquisition of these UFS must be done through a constructive process that covers all skills -grammatical, sociolinguistic, discursive and strategic competences- and where the student has the opportunity to participate actively and consciously. (Julià/Ortiz 2013: 499, author's translation) ${ }^{4}$

\subsection{Contrastive phraseology}

16 Contrastive phraseology is the area dedicated to investigate the equivalence of phraseological units between different languages. The symmetries or divergences between combinations of words are due to the presence or absence of these factors in each linguistic community. For example, Spanish and Italian languages have a common religious and historical background and this is reflected on various expressions.

17 Many phraseological units share the same semantic mechanisms of configuration and an interlingual agreement between the images that underlie the phraseological units. "All these conclusions are drawn in studies by Iñesta and Pamies (2001), implying the existence of metaphors that are not exclusively circumscribed to a given culture" (Corpas Pastor 2004: 21). "We talk about the globalization in phraseology not in the extreme meaning of the word, but as the convergence of phraseological elements fed by shared sources like linguistic universals, conceptual metaphors and cultural aspects" (Corpas Pastor 2004: 36). 


\section{Objectives} phraseology. The main aim of the experimentation is investigating the phraseological competence in the learning of a foreign language and which aspects are involved in it. This objective will have consequences in the didactic field, because analysing which are the factors that allow - or impede - the development of this competence will favour a better approach in language learning disciplines. The role of first and other languages, interlanguage influence, familiarity, and cognitive strategies will be considered as main factors.

19 I think this research is constructive in the field of interlanguage influence (IIL) ${ }^{5}$, where the effect of second languages by plurilinguals has been underexplored, since attention has been more focused on the effect of mother-tongue languages. In my article I intend to deepen the understanding of the strategies applied by learners according to their linguistic profile, and analyse by which influences their learning is affected, either in positive or negative ways.

\section{Assumptions}

\section{a) The broader a learner's linguistic background is the higher is the phraseological competence in a foreign language (interlinguistic influence).}

The measure of the linguistic background will be considered according to each learner's previous known languages, including dialects, native and foreign languages. To be more concrete, I will focus on three aspects of phraseological competence, which are comprehension, translation and metalinguistic knowledge of phraseological elements. For instance, deriving from the first assumption, it is considered that the broader a learner's linguistic background is the greater is the intercomprehension of unknown elements of the target language. It is also assumed that this intercomprehension will be higher in bilinguals - or plurilinguals -, or to say it in another way, intercomprehension will be proportional with the language proficiency level of other languages different from the own.

\section{b) Familiarity will be a significant factor when considering the phraseological and metaphorical competence of learners who deal with foreign language elements (encyclopaedic knowledge).}

This will confirm the hypothesis that culture is a determinant factor when applying comprehensive and learning strategies. In the state of the art we mentioned that the whole brain acts when aiming at meaning, and so other cognitive aspects are essential to ensure a complete understanding, where encyclopaedical knowledge and culture are components of a same cognitive network. It is important, thus, to include these aspects in the didactic field, as they point directly to meaning. As a result, it is assumed that the familiarity the students in this research display towards certain elements presented in the study will be decisive in their phraseological and metaphorical competence. On 
the other hand, this assumption defends the notion according to which learners have more success interpreting idioms when these are presented with supportive context than without it (cf. Levorato, Cacciari 1999; Ishida 2008).

\section{c) Cognitive strategies vary depending on the semantic compositionality (semantic compositionality influence).}

It can be assumed that the greater the semantic transparency is the greater is the ability to interpret correctly a phraseological element. It also concurs with the metasemantic hypothesis (cf. Nippold, Rudzinski, 1993), according to which the learner tries to infer the non-literal meaning from the literal meaning of the expression. This is linked to the thesis by Levorato and Cacciari $(1995,1999)$ claiming that meaning of the components is the gateway to the meaning of the phraseological element. Consequently, in transparent phraseological elements, subjects will tend to give more idiomatic interpretations, while in opaque ones they will tend to give literal interpretations. Thus, their figurative competence (cf. Levorato/Cacciari 1995), which is their ability to interpret a message idiomatically, will be reduced in these cases. Previous studies on this topic have been developed by Núñez (2016), where the results pointed to a confirmation of the thesis by Levorati-Cacciari and Nipolds-Rudzinski. In Núñez's study, students decodified the individual parts of an opaque phraseological expression to confer a literal meaning. On the contrary, in transparent expressions, they tended to give idiomatic answers. He also demonstrated the important role of the first language, in some cases driving to a wrong answer.

\section{d) Cognitive strategies vary depending on the intercultural knowledge (intercultural influence).}

This assumption is related to the first one, as it is implicit that previous knowledge of familiar languages will bring interference in the phraseological competence achievement, not only due to linguistic elements but also as a consequence of the common cultural background these languages share. In Nuñez's studies (2016), it was also demonstrated the important role of the first language when interpreting phraseological units.

\section{Research methodology}

\subsection{Interpretation method}

A qualitative approach is applied to analyse the data according to an interpretative paradigm. In qualitative investigation, the methodology for the examination is based on cases. Consequently, the aim is not to represent data by variables, but it is to be focused on circumstances. Traditionally, qualitative investigation has approached its topic of study by classifying the subjects in types, which share common characteristics according to the factors considered. This will lead to an understanding of the social actor's role, not to the systematization of the variables as in the positivist paradigm (cf. Corbetta 2003). 


\subsection{Subjects} Culture Europee, specialized in Spanish language. Consequently, they already have a good command of language, with a homogenous level of B2 in all the participants. They also have a common profile academically speaking, as they are all students of linguistics subjects and have good notions of translation and language strategies.

\subsection{Adopted methodology}

26 A rehearsal exploration is done with a sample group, to provide a test. This stage is necessary in the research, as it allows the identification of possible inaccuracies in the methodology. The results are not to be included in the final results. Next, experimentation with the main group is carried out, leading to the final results. The first step is to describe the subjects' linguistic profile in order to create convergences and divergences. Subjects share an academic and linguistic background, but particularities are to be analysed as a first step. The elements considered are knowledge, level and context of use of various languages, including native, dialectal and regional languages, Spanish and other foreign languages.

The corpus is formed by headlines extracted from the covers of Spanish newspapers, concretely from "El País", during the first three months of 2017. The goal is to retrieve phraseological expressions and metaphors appearing in the informative headlines to build the material for the applied experimentation. A total of 26 metaphorical or figurative expressions have been selected during these three months.

Informative texts from covers in newspapers have been chosen because of their characteristics. First of all, apart from informing and communicating, these kinds of texts should also bring an aesthetic value. They should reach the reader's heart and mind, and do it in a -linguistically speaking- economical and clear way. Secondly, the use of linguocultural clichés in the press is a known way of concentrating information and creating image. It is, besides, "a magnificent method to attract the reader's attention to the most relevant element of all the journalistic information: the headline" (Mironesko 2015: 175-176).

Headlines are important in their own way. They are the first text that a newspaper reader sees when buying and reading the paper. They employ a range of creative language devices to produce short attention getting highly memorable texts, and have the capacity to encapsulate an entire story in a few words. (Reah 1998: 32)

The other reason why this corpus has been chosen is because of the abundance of phraseological elements in this media. As Capra affirms,

[...] a paremiological study (Corpas, 1998) based on a varied and consistent corpus of current Spanish has come to the conclusion that the greatest concentration of proverbs (including quotations) lies in journalism, with 35,5\% of occurrences; followed by orality, with $25 \%$. Moreover, in $40 \%$ of cases the paremiological expression appears formally modified. (Capra 2008: 100, author's translation)

Indeed, as stated by Navarro (2001: 203-206), "there are three functions that phraseological elements accomplish in the text, and for which they are suitable for press headlines". Firstly, a phraseological function (as denominated by Zuluaga), in order to simplify both the message and its reception. In fact, even though its brevity and concision, phraseological elements express contents of complexity. Secondly, their 
connotative function, because they give indirect or additional values to the discourse. And last, Navarro assigns an iconic function to some phraseological units, which consists in the representation of the context through images, allowing information to be perceived with more agility -related to the literal and figurative meaning.

31 A referential publication for my project is Fernández Álvarez (2011), where the author extracts a real corpus from German press to analyse its possible Spanish translation. In addition, the work by Ruiz (2000) has been a reference, where an interesting analysis of the metaphors employed in a piece of news is developed in order to study the idealized cognitive models involved in it. Other work that has inspired me is Capra's recollection of phraseological expressions in Italian and Spanish newspapers during a period of time to establish and compare their concurrence (2015).

In the core of the experiment, the corpus is presented to the subjects. Two parts are developed. The first part consists of a whole-group exposition and discussion, to make the subjects familiar with both the material and the methodology. The second part is more individually-focused, in order to achieve conclusive results for the assumptions. A discussion with the subjects will be established to see how they interpret these phraseological elements, by answering to three main tasks: explaining them, translating them to Italian, and explaining which elements are conclusive to understand the meaning of the expression. Especially during the first whole-group part, clarification of the four cognitive concepts to be considered in the studies is made -linguistical, contextual, metaphorical and intercultural elements.

After the experimentation, the individual part is key to analyse thoroughly the strategies used in the exercises and to discern what are the roles of interlanguage, context, encyclopaedic knowledge and semantic compositionality in the correct interpretation of the expressions. In the individual-work part, the expressions are shown and the subjects develop the task individually. The subjects answer to the tasks individually, explaining the expressions, translating them to Italian and describing which elements are conclusive to understand the meaning of the expression.

\section{Results}

The answers given by the subjects are to be classified in four categories: idiomatic, literal, feasible or wrong answer, to assess the subjects' comprehension level and discover the kind of interpretation they $\mathrm{do}^{6}$.

\section{a) Result 1: Linguistic profile and phraseological competence}

Assumption 1: The broader a learner's linguistic background is the higher is the phraseological competence in a foreign language.

We analyse how the linguistic profiles relate to the competence achieved in the experimentation. The results have partly confirmed the assumption.

\begin{tabular}{|l|l|l|l|}
\hline LINGUISTIC PROFILE & $\begin{array}{l}\text { SUBJECTS (identification } \\
\text { number) }\end{array}$ & $\begin{array}{l}\text { NUMBER OF } \\
\text { STUDENTS }\end{array}$ & $\begin{array}{l}\text { APPROXIMATE } \\
\text { PERCENTAGE }\end{array}$ \\
\hline
\end{tabular}




\begin{tabular}{|c|c|c|c|}
\hline $\begin{array}{l}\text { High bilingualism (good knowledge } \\
\text { of } 2 \text { languages), with high-level of } \\
\text { Spanish }\end{array}$ & 14,40 & 2 & $4,5 \%$ \\
\hline $\begin{array}{l}\text { Low bilingualism (knowledge of } 2 \\
\text { languages, } 1 \text { strong and } 1 \text { weak), } \\
\text { with high-level of Spanish }\end{array}$ & 30,41 & 2 & $4,5 \%$ \\
\hline $\begin{array}{l}\text { Low bilingualism (knowledge of } 2 \\
\text { languages, } 1 \text { strong and } 1 \text { weak), } \\
\text { with low-level of Spanish }\end{array}$ & 17,19 & 2 & $4,5 \%$ \\
\hline $\begin{array}{l}\text { High plurilingualism (good } \\
\text { knowledge } 2 \text { or } 2+\text { languages), with } \\
\text { high-level of Spanish }\end{array}$ & $2,5,10,11,24,27,28,29$ & 8 & $18 \%$ \\
\hline $\begin{array}{l}\text { High plurilingualism (good } \\
\text { knowledge of } 2 \text { or } 2+\text { languages), } \\
\text { with low-level of Spanish }\end{array}$ & 7 & 1 & $2,25 \%$ \\
\hline $\begin{array}{l}\text { Low plurilingualism (knowledge of } \\
2 \text { or } 2+\text { languages, some strong and } \\
\text { some weak), with high-level of } \\
\text { Spanish }\end{array}$ & $\begin{array}{l}3,4,6,9,12,15,16,18,20,22, \\
23,25,26,31,32,33,34,35 \\
36,37,38,39,42,43,44,45\end{array}$ & 26 & $58 \%$ \\
\hline $\begin{array}{l}\text { Low plurilingualism (knowledge of } \\
2 \text { or } 2+\text { languages, some strong and } \\
\text { some weak), with low-level of } \\
\text { Spanish }\end{array}$ & $1,8,13,21$ & 4 & $9 \%$ \\
\hline
\end{tabular}

Table 1: Linguistic profile and phraseological competence

The measure of the linguistic background has been elaborated regarding the learners' previous known languages, including dialects, native and foreign languages. The main hypothesis established that the intercomprehension of unknown elements in the target language is directly proportional to the broadness of the learner's linguistic background. Besides, the intercomprehension was supposed to be higher correspondingly to the level of bilingualism or plurilingualism of the subjects.

From the results retrieved, the hypothesis is partly confirmed, as the higher phraseological and metaphorical competence shown in correct results are seen in the categories of high bilingualism with high-level of Spanish and with high plurilingualism and low-level of Spanish. The same seems to be revealed by the group with low bilingualism and low-level of Spanish, which attains the lowest metaphorical competence level, outcome that is coherent with the assumption.

However, the group of students with low plurilingualism and high-level of Spanish and the one formed by high plurilinguals with high-level of Spanish contradict the previous conclusions, as the metaphorical and figurative competence of the students in these categories are inferior, even if their linguistic background is supposed to be rich. The result obtained by the group with low plurilingualism and low-level of Spanish is also contradictory, as they acquire a surprisingly high score. 
40 In conclusion, these contradictions observed do not allow a confirmation of the assumption. Consequently, it is necessary to affirm that the assumption is not fully accomplished.

\section{b) Result 2: Familiarity and phraseological competence}

Assumption 2: Familiarity will be a significant factor when considering the phraseological and metaphorical competence of learners who deal with foreign language elements.

We provide an analysis that summarizes the difference in the accomplishment in the tasks related to the corpus, comparing the familiar ones to the non-familiar ones. This systematization serves to see at what level does familiarity guide subjects to establish a relationship between the literal meaning and the non-literal meaning in each one of the cases. The results have partly confirmed the assumption.

\begin{tabular}{|l|l|l|}
\hline & Correct answers & Inadequate answers \\
\hline Familiarity & $29,8 \%$ & $7,3 \%$ \\
\hline No familiarity & $35,2 \%$ & $27,7 \%$ \\
\hline
\end{tabular}

Table 2: Familiarity and phraseological competence

The aim of this part of the investigation is to confirm the theory according to which culture is a determinant factor when applying comprehensive learning strategies. As a result, it is assumed that the familiarity the students in this research display towards certain elements presented in the study will be decisive in their phraseological and metaphorical competence.

Once again, the results point to a contradiction in this part of the investigation. Actually, the level of metaphorical and phraseological competence of the subjects is quite satisfactory. Thus, this homogeneity reveals an ambiguity that does not allow a total confirmation of the assumption. Nevertheless, the subtly low metaphorical competence displayed by the learners when the unfamiliarity level arises might point to a slight confirmation of the hypothesis. On the other hand, several factors that are clearly influencing on the abilities displayed by the learners have been considered and analysed, such as the intercultural influence, the metaphorical and figurative competence, and the encyclopaedic and contextual information, all of which might interact with one another and lead to equivocal results.

\section{c) Result 3: Semantic compositionality and phraseological competence}

Assumption 3: Cognitive strategies vary depending on the semantic compositionality.

We provide an analysis that summarizes what cognitive strategies are used in the interpretation phase of the experimentation with the corpus, relating it to the semantic compositionality of the phraseological elements. In this part, we concentrate on the semantic compositionality influence. 


\begin{tabular}{|c|c|c|c|c|c|c|c|c|c|}
\hline & $\begin{array}{l}\text { Idioma } \\
\text { interpr }\end{array}$ & ons & lequate & $\begin{array}{l}\text { Idioma } \\
\text { interp }\end{array}$ & ${ }^{i}$ & lequate & $\begin{array}{l}\text { Litera } \\
\text { interp }\end{array}$ & $\begin{array}{l}\text { in } \\
\text { tations }\end{array}$ & equate \\
\hline \multirow{4}{*}{ Compositional } & $96,2 \%$ & $77 \%$ & $52,6 \%$ & $3,7 \%$ & $14 \%$ & $33,1 \%$ & $0 \%$ & $8,9 \%$ & $14,2 \%$ \\
\hline & $\mathrm{T}$ & $1^{\text {st }}$ & $2^{\text {nd }}$ & $\mathrm{T}$ & $1^{\text {st }}$ & $2^{\text {nd }}$ & $\mathrm{T}$ & $1^{\text {st }}$ & $2^{\text {nd }}$ \\
\hline & \multicolumn{3}{|l|}{$75,3 \%$} & \multicolumn{3}{|l|}{$16,9 \%$} & \multicolumn{3}{|l|}{$7,7 \%$} \\
\hline & \multicolumn{6}{|l|}{$92,2 \%$} & \multicolumn{3}{|l|}{$7,7 \%$} \\
\hline \multirow{4}{*}{$\begin{array}{l}\text { Non- } \\
\text { compositional }\end{array}$} & $75,2 \%$ & $67,3 \%$ & $41,7 \%$ & $17,5 \%$ & $3,4 \%$ & $51,6 \%$ & $7,3 \%$ & $29,3 \%$ & $6,7 \%$ \\
\hline & $\mathrm{T}$ & $1^{\text {st }}$ & $2^{\text {nd }}$ & $\mathrm{T}$ & $1^{\text {st }}$ & $2^{\text {nd }}$ & $\mathrm{T}$ & $1^{\text {st }}$ & $2^{\text {nd }}$ \\
\hline & \multicolumn{3}{|l|}{$61,4 \%$} & \multicolumn{3}{|l|}{$24,2 \%$} & \multicolumn{3}{|l|}{$14,4 \%$} \\
\hline & \multicolumn{6}{|l|}{$85,6 \%$} & \multicolumn{3}{|l|}{$14,4 \%$} \\
\hline
\end{tabular}

Table 3: Semantic compositionality and phraseological competence

The hypothesis derived from this assumption is related to the idiomatic character of a phraseological unit, which is supposed to be inversely proportional to the learner's ability to interpret it correctly. Consequently, it is assumed that the learner will infer the non-literal meaning from the literal meaning of the expression (see the metasemantic hypothesis by Nippold, Rudzinski, 1993; and Levorato, Cacciari, 1995, 1999).

It is presumed that the meaning of the components in an expression is the gateway to access the meaning of the whole phraseological unit. As a result, in compositional elements subjects are supposed to give more idiomatic interpretations, while in noncompositional expressions, literal readings would prevail. As a consequence, in noncompositional cases, the metaphorical and figurative competence are supposed to be reduced, as the learners' ability to interpret a message idiomatically is to be reduced in the cases when the element does not present compositionality.

The results prove that the assumption is accomplished, even if with discrete observations. Certainly, in compositional phraseological units, the learners give more idiomatic interpretations, while in non-compositional cases they provide literal interpretations, thus displaying a lower ability to interpret a message idiomatically in expressions with a high degree of idiomatic character.

\section{d) Result 4: Cultural knowledge and phraseological competence}

Assumption 4: Cognitive strategies vary depending on the interlanguage influence.

51 We analyse how the linguistic profiles relate to the competence achieved in the experimentation, extracting in which cases the equivalence affects the interpretation, and at which grade it is either a positive interference or a negative one.

This assumption establishes that the phraseological and metaphorical competence is directly proportional to the degree of interlanguage equivalence. The hypothesis is 
confirmed. Nevertheless, an apparently contradictory outline is replicated in the examination, as there is the predisposition for the subjects to present a superior accuracy in the second partial equivalence, as related to the first equivalence cases. This might be explained by side factors such as the encyclopaedic knowledge of the students and the context of presentation of the elements. Besides, the learners might rely on other cognitive strategies in the cases where they detect that interlanguage equivalence is not as trustable as in other elements. Thus, the hypothesis according to which the decompositional process performed by the learners is to be different depending on the degree of equivalence is confirmed, even if not exactly in the tendency previously assumed.

Certainly, cognitive mechanisms are applied and modified in order to develop more effective strategies, and this fact might explain the incongruity presented in this part of the study. On the other hand, the adaptable character of the learning processes, where the language learners' flexibility allows them to adapt their metaphorical and figurative competence to the conditions of use and learning context, is once again proved.

Finally, the assumption is considered to be wholly accomplished, as in general terms the ability of the learners is better in the cases of total equivalence with regard to partial equivalent elements.

\section{BIBLIOGRAPHY}

BIRIS, Gabriela (2014): “La enseñanza de las unidades fraseológicas: aspectos específicamente culturales e interculturales”. Análisis textual en la comunicación intercultural, Actas del Congreso International Mapping Language Across Cultures/Topografías del Lenguaje entre culturas (MLAC10), ed. by Izaskun ELORZA \& Ovidi CARBONELL CORTÉs, Salamanca, 5-7 july 2010. Aquilafuente: Ediciones Universidad de Salamanca, 29-40.

CACCIARI, Cristina, TABOSSI, Patrizia. (1988): “The Comprehension df Idioms". Journal of Memory and Language: $66-83$.

CANDELIER, Michel et al. (2003): Challenges and Opportunities in Language Education The Contributions of the European Centre for Modern Languages 2000 - 2003. Graz: European Centre for Modern Languages. Council of Europe Publishing.

CAPRA, Daniela (2008): "Presenza e funzioni della fraseologia nel giornalismo economico: Italia e Spagna a confronto". Linguistica contrastiva tra italiano e lingue iberiche, Atti del XXIII Convegno AISPI, Palermo 6-8 ottobre 2005, ed. by Lorenzo BLINI, Maria Vittoria CALVI and Antonella CANCELLIER. Madrid: Instituto Cervantes-AISPI, 89-103. COMPAGNO, Giuseppa, DI GESÙ, Floriana (2013). Neurodidattica, Lingua e Apprendimenti: riflessione teorica e proposte operative. Roma: Aracne editrice. CORBETTA, Piergiorgio (2003): Metodología y técnicas de investigación social. Madrid: McGraw-Hill. 
CORPAS PASTOR, Gloria (2004): “La globalización de la fraseología como convergencia cultural”. Letras de Hoje, vol.:39, iss: 1: 9-43.

COUNCIL OF EUROPE (2001a): Common European Framework of Reference for Languages: Learning, Teaching, Assessment. Cambridge: Cambridge University Press.

CUMMINS, Jim (2000): Language, power and pedagogy: bilingual children in the crossfire. Clevedon: Multilingual Matters.

FERNÁNDEZ ÁLVAREZ, Eva (2011): Refranes y refranes modificados en la prensa alemana. Propuestas prácticas de traducción al español a partir de ejemplos de la Süddeutsche Zeitung. Tesis doctoral. Salamanca: Universidad de Salamanca.

HERDINA, Philip, JESSNER, Ulrike (2002): A dynamic model of multilingualism perspectives of change in pshycolinguistics. Clevedon: Multilingual Matters.

HIGUERAS GARCÍA, Marta (2006): Estudio de las colocaciones léxicas y su enseñanza en español como lengua extranjera. Malaga: ASELE. (Colección Monografías, nº 9)

IÑESTA MENA, Eva, PÀMIES BERTRÁN, Antonio (2002): Fraseología y metáfora: aspectos tipológicos y cognitivos. Granada: Granada lingvistica.

ISHIDA, Priscilla (2008): “The effect of context on L2 learner strategies for idiom interpretation". Studies in Language and Literature (Language) 54: 107-145.

JULIÀ, Carolina, ORTIZ, Cristina (2013): “La semántica cognitiva en la enseñanza-aprendizaje de las unidades fraseológicas en ELE: el ejemplo de los somatismos". Plurilingüismo y enseñanza de ELE en contextos multiculturales. XXIII Congreso Internacional ASELE, ed. by Beatriz BLECUA, Berta CROUS, Fermín SIERRA, Sara BORRELL. Madrid: Asociación para la Enseñanza del Español como Lengua Extranjera, 495-507.

LEVORATI, Maria Chiara, CACCIARI, Cristina (1995): “The effects of different tasks on the comprehension and production of idioms in children". Journal of Experimental Child Psychology 60: 261-283.

LEVORATI, Maria Chiara, CACCIARI, Cristina (1999): "Idiom comprehension in children: Are the effects of semantic analysability and context separable?". European Journal of Cognitive Psychology 11/1: 51-66.

LUQUE DURÁN, Juan de Dios (2004): Aspectos universales y particulares de las lenguas del mundo. Granada: Impredisur S. L (Estudios de Lingüística del Español. Vol. 21.)

MARTÍ SÁNCHEZ, Manuel (2016): “¿Qué es la competencia fraseológica? Preguntas y alguna respuesta". Gutta cavat lapidem. Indagini fraseologiche e paremiologiche, ed. by Elena DEL MASO, Carmen NAVARRO: Mantova. Universitas Studiorum, 55-68.

MELLADO BLANCO, Carmen (2013): “La gramaticalización de las restricciones y preferencias de uso de las unidades fraseológicas del español y alemán desde un enfoque cognitivo-pragmático". Fraseopragmática., ed. by Inés OLZA, Elvira MANERO. Berlin: Frank \& Timme, 303-331.

MIRONESKO, Elena (2005): “Apotegmas rusos como medio de creación del titular periodístico”. La creatividad en el lenguaje. Colocaciones idiomáticas y fraseología, ed. by Juan de Dios LUQUE DURÁN, Antonio PAMIES BERTRÁN. Granada: Granada Lingvistica (Serie Collectae), 175-188.

NAVARRo, Carmen (2001): “La fraseología en el discurso político y económico de los medios de comunicación". Testi specialistici e nuovi saperi nelle lingue iberiche, Atti del XX Convegno dell'AISPI, ed. 
by Domenico Antonio cuSATo, Loretta FRATTALE. Firenze 14-17 marzo 2001. Madrid: Instituto Cervantes-AISPI, 199-211.

NAVARRo, Carmen (2003): "Didáctica de las unidades fraseológicas". Didáctica del léxico y nuevas tecnologías, ed. by Maria Vittoria CALVI, Felix SAN VICENTE. Viareggio-Lucca: Mauro Baroni Editore, 99-115.

NIPPOLD, M. A., RUDZINSKI, M. (1993): "Familiarity and Transparency in Idiom Explanation: A Developmental Study of Children and Adolescents". Journal of Speech and Hearing Research 36/4: 728-737.

NÚÑEZ ROMAN, Francisco (2015): “Enseñar fraseología: consideraciones sobre la fraseodidáctica del español”. Didáctica. Lengua y Literatura vol. 27: 153-166.

NÚÑEZ ROMAN, Francisco (2016): “La adquisición de unidades fraseológicas en lengua materna vs. los procesos de enseñanza-aprendizaje en segundas lenguas: factores diferenciales". Fraseologia Contrastiva: Lingue e culture a confronto. Congress in Università degli Studi di Milano. 9-11 novembre 2016.

ODLIN, Terence (1989): Language transfer: Cross-linguistic influence in language learning. Cambridge: University Press

REAH, Danuta (1998): The Language of Newspapers. London / New York: Routledge.

SEVILLA MUÑOZ, Julia (2007): “Civilización y Cultura. La base cognitiva de una cultura tradicional”. Eslavística Complutense 7: 159-170.

\section{NOTES}

1. Experiments to examine people's understanding and memory for idioms indicate that, in a conversational context, subjects take less time to comprehend conventional uses of idiomatic expression than in unconventional literal uses. Paraphrase judgment errors show that there is a strong bias to interpret idiomatic expressions conventionally when there is no preceding context. However, subjects interpret literal uses of these expressions correctly when there is appropriate context.

2. Cacciari has undertaken considerable research on the field of acquisition of phraseology, from the physiological perspective. In priming experiments, she investigated the access to idiomatic expressions, to see when subjects do faster in predicting an idiomatic meaning, whether the idioms were idiomatically or literally related. Her results showed a confirmation of previous research which had ruled out the view that people perform a literal analysis of an idiomatic string before they initiate a nonliteral interpretation. On the other hand, she reaffirms that an idiom cannot be recognized before a certain amount of information has been received (cf. Cacciari/Tabossi 1988).

3. Cacciari stated that "the well-known role of context in literal language comprehension is probably more crucial with idioms. In fact, what is peculiar about these expressions is that if taken literally they sometimes make no sense but, nevertheless, they do fit in an appropriate context" (Cacciari/Tabossi 1988: 14).

4. Julià presents a methodological proposal based on cognitive postulates where she supports a transversal method in which the idiomatic expressions are present from the initial stages of language learning to the end. She also proposes that the four language skills be treated in a gradual and progressive way, presenting phraseological elements in relation to its origin, motivation and underlying cognitive scheme, in order to facilitate its global comprehension and 
allowing students to establish general comparisons with the language they already have. It is, therefore, a procedure in which the learner is intended to create cognitive and conceptual correspondences between the languages he knows and new ones.

5. IIL can be defined as the interaction between previous languages and the target language, or more specifically, "the influence resulting from similarities and differences between the target language and any other language that has been previously (and perhaps imperfectly) acquired" (Odlin 1989: 27).

6. Based on Núñez Roman, F. (2016): "La adquisición de unidades fraseológicas en lengua materna vs. los procesos de enseñanza-aprendizaje en segundas lenguas: factores diferenciales". In Fraseologia Contrastiva: Lingue e culture a confront. Congress in Università degli Studi di Milano. 9-11 novembre 2016.

\section{ABSTRACTS}

This article analyses the interlanguage effect in the learning process of Spanish phraseology by native Italians. The plurilingual profile that Italian inhabitants naturally have provides a fruitful field to examine the impact of their linguistic profile on their learning process of a foreign language. Phraseology is a fundamental face of the communication act as it blends into language features related to history and culture. In a globalised society like today's, it is important to advance these viewpoints as they help to develop a richer society with a more respectful approach to diversity. Phraseodidactics, therefore, is presented as a basic feature of communication to be integrated in foreign language teaching. The context of the application of this research is the Italian University of Modena (Università degli Studi di Modena), which offers specific studies regarding European cultures. This article intends to investigate the interactions between native languages and the learning process of a foreign language in the light of previous investigation on the area of phraseology and its didactics.

Cet article analyse l'effet de l'interlangue dans le processus d'apprentissage de la phraséologie espagnole par les Italiens natifs. Le profil plurilingue que les locuteurs italiens ont naturellement fournit un champ fructueux pour examiner l'impact de leur profil linguistique sur leur processus d'apprentissage d'une langue étrangère. La phraséologie est un aspect fondamental de l'acte de communication car elle se base sur les caractéristiques linguistiques liées à l'histoire et à la culture. Dans une société mondialisée comme celle d'aujourd'hui, il est fondamental d'améliorer ces points de vue car ils contribuent à développer une société plus riche avec une approche plus respectueuse de la diversité. La phraséodidactique est donc présentée comme une caractéristique de base de la communication à intégrer dans l'enseignement des langues étrangères. Le contexte d'application de cette recherche est l'Université italienne de Modène (Università degli Studi di Modena), qui propose des études spécifiques sur les cultures européennes. Cet article se propose d'étudier les interactions entre les langues maternelles et le processus d'apprentissage d'une langue étrangère à la lumière des recherches antérieures sur le domaine de la phraséologie et de sa didactique. 
INDEX

Mots-clés: Phraséologie, interlangage, plurilinguisme, phraséodidactique, italien

Keywords: Phraseology, interlanguage, plurilingualism, phraseodidactics, Italian

\section{AUTHOR}

\section{ESTER MELLADO BLANES}

Universitat Pompeu Fabra Barcelona 